\section{Birlesik Dunya Arastrrma Cypriot Journal of Educational \\ Sciences}

Volume 16, Issue 2, (2021) 451-467

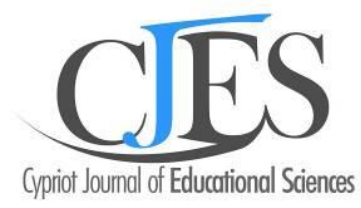

www.cjes.eu

\title{
Examination of educators' self-efficacy for effective communication
}

\author{
Ömer Yahşi ${ }^{a}{ }^{*}$, İzmir Provincial Directorate of National Education, Fevzipaşa, 452 Sk. 15A, İzmir 35260, Turkey \\ https://orcid.org/0000-0003-3872-6010
}

\section{Suggested Citation:}

Yahşi, Ö (2021). Examination of educators' self-efficacy for effective communication. Cypriot Journal of Educational Science. 16(2), 451-467 https://doi.org/10.18844/cjes.v16i2.5622

Received from November 11, 2020; revised from January 30, 2021; accepted from April 12, 2021.

${ }^{\circ} 2021$ Birlesik Dunya Yenilik Arastirma ve Yayincilik Merkezi. All rights reserved.

\begin{abstract}
The aim of this study is to determine the perceptions of self-efficacy, effective communication skills of administratorsand teachers in Izmir. For learning processes to be effective, it is very important that educators have effective communication skills and develop their self-awareness in this regard. Determining the effective communication self-awareness of educators will contribute to the literature and guide higher policy practices. This study considers the following questions: Is there a significant difference in effective communication self-efficacy subscale scores according to educators' task type and gender, years of service and branch? This study uses the scanning model, a quantitative research method. The data collection tool consists of two parts: first, personal information about the educators; second, the scale items of the Effective Communication Self-Efficacy Inventory. The Inventory was consists of 41 items. Four main results were obtained from the findings of this study. A significant difference was found in favor of managers in all three subscales of the inventory. This can be explained by the fact that administrators see communication as a more necessary requirement than do teachers, in order to better maintain the education process.
\end{abstract}

Keywords: administrators, communication skills, self-efficacy, administrators-teachers.

\footnotetext{
* ADDRESS FOR CORRESPONDENCE: Ömer Yahşi, İzmir Provincial Directorate of National Education, İzmir, 35260, Turkey E-mail address: oyahsi@gmail.com / Tel.: 0532-5963660
} 
Yahşi, Ö (2021). Examination of educators' self-efficacy for effective communication. Cypriot Journal of Educational Science. 16(2), 451-467 https://doi.org/10.18844/cjes.v16i2.5622

\section{Introduction}

The ability of people to transfer their emotions and skills to others, in short, communication, means the creation of social and cultural-based institutions with certain rules, values that survive for centuries. Communication has an important role not only in the development of the wider social order and also in educational institutions. Communication is generally defined as an interaction process that results in common meanings of knowledge, ideas, attitudes, feelings, skills, and affects a change in behavior between the source and the target (Çetinkanat, 1998). A basic definition is the transfer and sharing of information (Bagin et al., 2008; Heslep, 1998). Bagin defines communication as a collaboration, requiring the mutual exchange of ideas and information (Bagin et al, 2008). Communication is the transmission of information from the source to the receiver, the significance of events that take place between the source and the receiver (Atik, 2009). Effective communication, which includes the process of transferring, contacting, understanding, expressing to others, is associated with effective communication skills (Buluş, Atan, \& Sarıkaya, 2017).

One of the most important elements of the education system is that school leaders and teachers have effective communication skills, particularly for understanding and being sensitive towards others (Çetinkaya \& Alparslan, 2011). Effective communication is essential for improving school performance, transferring the results to the school community. According to Kowalski (2006), administrators need to seek community support to develop and implement a common vision for successful students, schools; in order to achieve this they must have the skills necessary for a communication leader. Meek (1999) warns that successful communication during a crisis can only be achieved if effective lines of communication are established prior to a crisis occuring. These lines should be established between the adminstrator, school staff, parents and the public (Bagin, Gallagher \& Moore, 2008; Meek, 1999).

The importance of communication, communication skills in educational institutions cannot be denied. Healthy communication between school leaders, teachers affects students, parents, all other stakeholders positively and creates a positive organizational climate (Doğan, Uğurlu, Yıldırım \& Karabulut, 2013). There are some opinions stating that without effective organizational communication, even the best strategies or well-prepared plans would fail (Stewart, Martin \& Tyrone, 2005). One study observed that the effective communication skills of one school leader positively affected the school climate (Halawah, 2005). Guerrero and Floyd (2005) state that indivuduals with with effective communication skills have the power to influence others and that effective communication strategies lead to success.

Overcoming communication barriers, the use of effective communication skills are related to communication self-efficacy. Bandura (1997) states that an administrator's sense of self-efficacy determines the effectiveness of his/ her work within the scope of his/her skills, experiences. The school administrators perception of their self-efficacy is effective in success. Cotton (2003) underlines the importance of school administrators possessing many skills for their continuous development. These skills are necessary for other individuals in the educational environment. Bandura (1986) argues that individuals who see themselves as competent think, act differently from individuals who consider themselves incompetent. Stating that individuals with strong self-efficacy behave according to the situation and try harder to cope with difficulties, Bandura (1997) argues that school leaders' perceptions of their self-efficacy is an assessment of their ability to achieve the desired results. Smith, Guarino, Strom, and Reed (2003) emphasize the importance of an administrator's self-efficacy in creating an effective teaching, learning environment in a school. An administrator's perception of their self-efficacy can be seen as an important factor in increasing the motivation and efficiency of teachers, students within an institution (Tschannen-Moran \& Gareis, 2004). Teachers' perception of their self- 
Yahşi, Ö (2021). Examination of educators' self-efficacy for effective communication. Cypriot Journal of Educational Science. 16(2), 451-467 https://doi.org/10.18844/cjes.v16i2.5622

efficacy are considered important for student learning. It has also been found that teachers with high self-efficacy have higher levels of participation, as well as a positive effect on student motivation and success (Raufelder et.al 2013).

The quality of communication between an administrator and teachers can affect the achievement of the school's goals. The formation of a democratic school environment and effective achievement of school goals depend on two-way communication between the administrator and teachers and on the quality of this communication (Şimşek \& Altınkurt, 2009). A study conducted with classroom teachers revealed that classroom teachers perceive themselves as competent in communication self-efficacy (Aküzüm \& Gültekin, 2017). A study by Çınar (2010) identified the positive effectiveness of school administrators in the communication process. Another study found that the dimensions of administrators' communication skills, perceptions, gender, appearance, defensive behavior, knowledge, needs, listening skills, and empathy were found to be effective, but concluded that these skills should be developed (Şimşek \& Altınkurt, 2019).

Because having effective communication skills requires certain experience, gaining these skills is a reflection of educators' previous experiences. For this reason, the pre-service period is also important. Studies on the communication skills of pre-service teachers identify a medium or above average level of teacher candidates' perceptions of their communication skills (Çetinkaya \& Alparslan, 2011; Saracaloğlu, Yenice, \& Karasakaloğlu, 2009; Gürşimşek, Ekinci, \& Selçioğlu, 2008; Baykara \& Pehlivan, 2005).

Considering studies on effective communication and self-efficacy generally, those studies conducted mainly in the field of health, particularly those on developing effective communication skills in nurses and doctors observed that training programs would increase employees' communication skills (Khodadadi, et al., 2013; Doyle, et. al, 2011; Shama et. al, 2009; Bylund, et al., 2008). A study that synthesized the role and the importance of interpersonal effectiveness and communication competence in corporate compoetitiveness emphasizes the importance of oral and written communcation skills in the business education curriculum (Okoro, Washington and Thomas, 2017). This suggests that communication skills can be improved. Another study conducted to determine the effects of interpersonal communication skills on organizational commitment shows the skill of team building has a significant role in organizational commitment (Martin et. al, 2010) Afurther study examined the knowledge, attitudes, and performance of faculty of medicine members in terms of effective communication skills and observed that although the study participants' knowledge was insufficient, they had a positive attitude and relatively acceptable performance in communication skills (Sharifiad, Rezaeian, Jazini, \& Etemadi, 2020).

Studies have been conducted to examine various variables in the opinions of teachers and school administrators on communication skills. A study by Ceylan (2008) found that male teachers had lower communication skills than female teachers. Other studies do not show any differences according to the variable of gender (Memduhoğlu, 2015; Taşkın \& Hacıömeroğlu, 2010; Şimşek, 2003). Given that communication skills, motivation in the working environment are two important factors in the development of teachers, communication skills and work motivation are closely related (Majid, Jelas, Azman, \& Rahman, 2010). When classroom teachers' communication skills in relation to the dimensions of empathy, equality and effectiveness were examined, female teachers communicated with students more competently than male teachers (Erdem \& Okul, 2015).

The aim of this current study is to determine the perceptions of self-efficacy and effective communication skills of administrators, vice-principals and teachers in Izmir. For learning processes to 
Yahşi, Ö (2021). Examination of educators' self-efficacy for effective communication. Cypriot Journal of Educational Science. 16(2), 451-467 https://doi.org/10.18844/cjes.v16i2.5622

be effective, it is very important that educators have effective communication skills and develop their self-awareness in this regard. Considering that educators are those who direct societies, it must be remembered that their awareness of communication skills self-efficacy will affect stakeholders in the school microsystem as a whole. Considered in this context, it is thought that determining the effective communication self-awareness of educators will contribute to the literature and guide higher policy practices.

Accordingly, this study considers the following questions:

Is there a significant difference in effective communication self-efficacy subscale scores according to educators' task type?

Is there a significant difference in effective communication self-efficacy subscale scores of educators by gender?

Is there a significant difference in effective communication self-efficacy subscale scores of educators according to years of service?

Is there a significant difference in effective communication self-efficacy subscale scores according to educators' branch of study?

\section{Method}

This study uses the scanning model, a quantitative research method. The scanning model is a research model that aims to describe a past or current situation as it exists (Karasar, 2006).

\subsection{Participants}

The participants of the study are administrators and teachers working in state schools affiliated to Izmir Directorate of National Education, Turkey. The data collection tool was sent electronically, the branches with low numbers were removed from the data set in line with the feedback. Gender, job type, years of service, and teaching branch were taken into consideration and a total of 638 participants were determined using the random sampling method. Finally, outliers were removed from the data set, making a final sample size of 583. The distribution of the educators included in the sampling is presented in Table 1.

Table 1: Demographic characteristics of educators participating in the study

\begin{tabular}{llll}
\hline & & Frequency & $\%$ \\
\hline \multirow{3}{*}{ Gender } & Female & 337 & 57.8 \\
& Male & 246 & 42.2 \\
\cline { 2 - 4 } & Total & 583 & 100.0 \\
\hline \multirow{3}{*}{ Job Type } & Administrator & 221 & 37.9 \\
& Teacher & 362 & 62.1 \\
& Total & 583 & 100.0 \\
\hline \multirow{2}{*}{ Years of Service } & Between 1-10 & 126 & 21.6 \\
& Between 11-20 & 205 & 35.2
\end{tabular}


Yahşi, Ö (2021). Examination of educators' self-efficacy for effective communication. Cypriot Journal of Educational Science. 16(2), 451-467 https://doi.org/10.18844/cjes.v16i2.5622

\begin{tabular}{lll} 
More than 20 & 252 & 43.2 \\
\cline { 2 - 3 } Total & 583 & 100.0 \\
\hline Classroom teacher & 47 & 8.1 \\
Turkish & 40 & 6.9 \\
Elementary Mathematics & 42 & 7.2 \\
Technology and Design & 44 & 7.5 \\
Science & 40 & 6.9 \\
Turkish Language and Literature & 40 & 6.9 \\
Arts & 39 & 6.7 \\
Physical Education & 44 & 7.5 \\
Pre-school & 40 & 6.9 \\
Guidance and Psychological Counseling & 41 & 7.0 \\
Teacher of mentally handicapped & 44 & 7.5 \\
Religious Culture and Ethics & 38 & 6.5 \\
English & 44 & 7.5 \\
Social Science & 40 & 6.9 \\
\hline Total & 583 & 100.0 \\
\hline
\end{tabular}

The results of the descriptive analysis show the demographic characteristics of the participants to be as follows: by gender, $57.8 \%(f=337)$ are female educators and $42.2 \%$ are male educators $(f=246)$; by job type, $37.9 \%(f=221)$ are adminstrators; $62.1 \%(f=362)$ are teachers; by years of service, $21.6 \%$ $(f=126)$ have $1-10$ years, $35.2 \%(f=205)$ have $11-20$ years, $43.2 \%(f=252)$ have over 20 years. Looking at teaching branches, they are fairly evenly distributed although the largest group is classroom teachers ( $f=47 ; 8.1 \%$ ), the smallest group is religious culture and ethics teachers ( $f=38 ; 6.5 \%$ ). Differences in distribution are directly related to the demographic characteristics of the main population. However, in the process of selecting educators for the sample, care was taken that the difference between the groups did not exceed a multiple of 3 .

\subsection{Data Collection Tool}

The data collection tool consists of two parts: first, personal information about the educators' gender, job type, years of service, and teaching branch; second, the scale items of the Effective Communication Self-Efficacy Inventory. The Effective Communication Self-Efficacy Inventory was developed by Yahşi and Aydın (2020) to determine the self-efficacy perception of individuals in working life and consists of 41 items. It consists of 3 subscales of effective communication: Cognitive Self-efficacy (items 26, 40, 41, 47, 49, 51, 52, 55, , 57, 58, , 67, 69, and71), Affective Self-efficacy (items 14,15,17, 18, 19, 20, 21,33, 34, 35, 36, 43, 44, 50, 62, 64, and 68), Psychomotor Self-efficacy (items 10, 12, 29, 42, 60, 61, 63, 65, 66, 70 and 72). Exploratory Factor Analysis ( $f=727$ ), Confirmatory 
Yahşi, Ö (2021). Examination of educators' self-efficacy for effective communication. Cypriot Journal of Educational Science. 16(2), 451-467 https://doi.org/10.18844/cjes.v16i2.5622

Factor Analysis ( $f=210$ ), and Cronbach Alpha Reliability analyzes were used on the collected data. The Cronbach Alpha internal consistency coefficients calculated to determine the reliability of the scores obtained from the data collected groups for the Explanatory Factor Analysis (EFA) of the inventory were cognitive $(\alpha=.92)$, affective $(\alpha=.92)$, and psychomotor $(\alpha=.87)$. For the Confirmatory Factor Analysis (CFA) the scores were cognitive $(\alpha=.89)$, affective $(\alpha=.90)$, and psychomotor $(\alpha=.83)$. The Cronbach Alpha internal consistency coefficients related to the scores obtained from both groups shows that the scores obtained from the subscales with the whole measurement tool (EFA: .96; DFA: .91) were highly reliable.

\subsection{Analysis of Data}

In order to decide on which method to analyze the research findings, normality and homogeneity assumptions were examined. Kolmogorov-Smirnov and Shapiro-Wilk tests were conducted to determine whether the participants came from a normal distribution and the results are presented in Table 2.

Table 2: Normality test result table

\begin{tabular}{ccccccc}
\hline & \multicolumn{3}{c}{ Kolmogorov-Smirnov } & \multicolumn{3}{c}{ Shapiro-Wilk } \\
& Statistic & Df & Sig. & Statistic & df & Sig. \\
\hline JobType & .403 & 583 & .000 & .615 & 583 & .000 \\
Branch & .098 & 583 & .000 & .942 & 583 & .000 \\
Gender & .381 & 583 & .000 & .628 & 583 & .000 \\
$\begin{array}{c}\text { Years of } \\
\text { Service }\end{array}$ & .276 & 583 & .000 & .783 & 583 & .000 \\
$\begin{array}{c}\text { Cognitive Self- } \\
\text { efficacy }\end{array}$ & .109 & 583 & .000 & .965 & 583 & .000 \\
$\begin{array}{c}\text { Affective Sef- } \\
\text { efficacy }\end{array}$ & .089 & 583 & .000 & .975 & 583 & .000 \\
$\begin{array}{c}\text { Psychomotor } \\
\text { Self-efficacy }\end{array}$ & .098 & 583 & .000 & .975 & 583 & .000 \\
\hline
\end{tabular}

Table 2 shows that the participants' job type, teaching branch, gender, years of service, and subscales of the inventory do not have a normal distribution $(p<.05)$. Looking at skewness and kurtosis coefficients, the coefficient of +2 to -2 indicates that the scores show a normal distribution (Pallant, 2001). The cognitive self-efficacy, affective self-efficacy, and psychomotor self-efficacy subscales of job type, teaching branch, gender, years of service, and kurtosis and skewness coefficients of the inventory were found to be between +2 and -2 . Again, the histograms and plots related to the measurements were examined and it was decided that the scores showed a normal distribution. Considering homogeneity, the values were greater than 0.05 , so it was decided that the homogeneity assumption was sufficient for variance analysis. It was decided to do the research analysis with the independent t-test and one-way analysis of variance. Despite the homogeneous distribution of the groups according to years of service and teaching branch, the Gabriel test (Field, 2013) was used because these groups were not equal. 
Yahşi, Ö (2021). Examination of educators' self-efficacy for effective communication. Cypriot Journal of Educational Science. 16(2), 451-467 https://doi.org/10.18844/cjes.v16i2.5622

\subsection{Findings}

The scores for the first question of the study, whether there is a significant difference according to the job type in the cognitive, affective, and psychomotor self-efficacy subscale of the educators for effective communication, are presented in Table 3.

Table 3: Subscale independent t-test results by job type

\begin{tabular}{|c|c|c|c|c|c|c|c|}
\hline Subscale & Task type & $\mathrm{N}$ & $M$ & SD & $d f$ & $\mathrm{t}$ & $P$ \\
\hline \multirow[t]{2}{*}{$\begin{array}{l}\text { Cognitive self- } \\
\text { efficacy }\end{array}$} & $\begin{array}{c}\text { Administrat } \\
\text { or }\end{array}$ & 221 & 54.964 & 5.228 & 581.000 & 4.632 & 0.000 \\
\hline & Teacher & 362 & 52.721 & 5.926 & & & \\
\hline \multirow[t]{2}{*}{$\begin{array}{l}\text { Affective self- } \\
\text { efficacy }\end{array}$} & $\begin{array}{c}\text { Administrat } \\
\text { or }\end{array}$ & 221 & 72.656 & 6.458 & 581.000 & 2.480 & 0.013 \\
\hline & Teacher & 362 & 71.166 & 7.370 & & & \\
\hline \multirow[t]{2}{*}{$\begin{array}{c}\text { Psychomotor self- } \\
\text { efficacy }\end{array}$} & $\begin{array}{c}\text { Administrat } \\
\text { or }\end{array}$ & 221 & 45.801 & 4.486 & 581.000 & 2.193 & 0.029 \\
\hline & Teacher & 362 & 44.901 & 4.998 & & & \\
\hline
\end{tabular}

According to Table 3, the total scores of the scales of effective communication self-efficacy perceptions of administrators teachers show a significant difference in favor of administrators in all three subscales. When the cognitive self-efficacy results are examined, the administrators' total scores $(=54.96)$ are higher than the teachers' $(X=71.17), t(581)=4.63, p<.01$. Considering the cognitive self-efficacy scale in terms of arithmetic averages, educators in the position of administrator were very good $(4.23 ; S D=.40)$ and teachers were good $(4.06 ; S D=.46)$. The affective self-efficacy results show the total scores of cognitive self-efficacy in favor of managers are higher, $t(581)=2.48, p<.05$. The results of the affective self-efficacy scale analyzed in terms of arithmetic averages show that educators in the position of administrator were excellent $(4.27 ; \mathrm{SD}=.38)$ teachers were close to perfect (4.19; SD $=.43$ ). Finally, the results of the psychomotor scale for effective communication show administratos' total scores $(M=45.80)$ are higher than teachers', $t(581)=2.19, p<.05$. The results of the psychomotor self-efficacy scale analyzed in terms of arithmetic averages show that both the educators in the position of administrator $(4.16$; SD $=.41)$ and teachers $(4.08 ; \mathrm{SD}=.45)$ were good. The average scores of all three subscales show that effective communication self-efficacy is higher than the affective self-efficacy average in both administrators and teachers. These findings are important in terms of showing that educators feel themselves more competent in effective communication.

Results for the second question of the study, whether there is a significant difference according to gender in the cognitive, affective, and psychomotor self-efficacy subscale total scores of educators for effective communication are presented in Table 4. 
Yahşi, Ö (2021). Examination of educators' self-efficacy for effective communication. Cypriot Journal of Educational Science. 16(2), 451-467 https://doi.org/10.18844/cjes.v16i2.5622

Table 4: Subscale independent t-test results by job type

\begin{tabular}{llllllll}
\hline Subscale & Gender & $\mathrm{N}$ & $\mathrm{M}$ & $\mathrm{SD}$ & $\mathrm{df}$ & $\mathrm{t}$ & $\mathrm{p}$ \\
\hline Cognitive self-efficacy & Female & 337 & 53.190 & 5.665 & 581.000 & -1.871 & 0.062 \\
& Male & 246 & 54.093 & 5.884 & & & \\
\hline Affective self-efficacy & Female & 337 & 71.677 & 7.028 & 581.000 & -0.216 & 0.829 \\
& Male & 246 & 71.805 & 7.140 & & & \\
\hline Psychomotor self- & Female & 337 & 45.196 & 4.817 & 581.000 & -0.269 & 0.788 \\
efficacy & Male & 246 & 45.305 & 4.848 & & & \\
\hline
\end{tabular}

The findings presented in Table 4 show there is no significant difference between cognitive selfefficacy $(t=-1.87 ; p>.05)$, affective self-efficacy, $(t=-0.22 ; p>.05)$, psychomotor self-efficacy $(t=-$ $0.27 ; p>.05$ ). The arithmetic averages by gender show cognitive (Female: $4.09, S D=.44$; Male: 4.16 , $\mathrm{SD}=.45$ ); psychomotor self-efficacy (Female: 4.11, SD = .44; Male: 4.12, SD $=.44$ ) were at a good level, while affective self-efficacy was at an excellent level (Female: 4.22 , SD = .41; Male: 4.22, SD = .42). These results are important in terms of showing that affective self-efficacy in effective communication self-efficacy is higher in both women and men compared to other subscales such as job type.

The results for the third question of the study, whether there is a significant difference in the cognitive, affective, and psychomotor self-efficacy subscale scores of educators for effective communication according to years of service are presented in Tables 5 and 6.

Table 5: Analysis results of subscale scores by years of service

\begin{tabular}{lllll}
\hline Subscale & Years of Service & N & M & SD \\
\hline Cognitive self- & $1-10$ & 126 & 53.151 & 5.768 \\
Efficacy & $11-20$ & 205 & 52.810 & 5.668 \\
& More than 20 & 252 & 54.401 & 5.770 \\
& Total & 583 & 53.571 & 5.771 \\
\hline Affective self- & $1-10$ & 126 & 71.873 & 6.987 \\
Efficacy & $11-20$ & 205 & 70.620 & 6.886 \\
& More than 20 & 252 & 72.563 & 7.164 \\
& Total & 583 & 71.731 & 7.069 \\
\hline Psychomotor self- & $1-10$ & 126 & 45.278 & 5.069 \\
Efficacy & $11-20$ & 205 & 44.922 & 4.598 \\
& More than 20 & 252 & 45.484 & 4.887 \\
& Total & 583 & 45.242 & 4.826 \\
\hline
\end{tabular}


Yahşi, Ö (2021). Examination of educators' self-efficacy for effective communication. Cypriot Journal of Educational Science. 16(2), 451-467 https://doi.org/10.18844/cjes.v16i2.5622

Tables $5-6$ show the cognitive $(M=53.57)$ and affective self-efficacy $(M=72.56)$ of educators who worked for 11-20 years were significantly increased according to the cognitive $(M=52.81)$ and affective self-efficacy ( $M=70.62$ ) has been seen to be higher. According to professional processes, the affective self-efficacy of educators who worked for more than 20 years was excellent $(4.27 ; \mathrm{SD}=.42)$. A good level of effective communication self-efficacy was found in other subscales and for all service periods.

Table 6: Subscale variance analysis results by years of service

\begin{tabular}{|c|c|c|c|c|c|c|c|}
\hline Subscale & $\begin{array}{l}\text { Source of } \\
\text { Variance }\end{array}$ & $\begin{array}{l}\text { Sum of } \\
\text { Squares }\end{array}$ & Df & $\begin{array}{l}\text { Mean } \\
\text { Square }\end{array}$ & $\mathrm{F}$ & $\mathrm{p}$ & $\begin{array}{l}\text { Significant } \\
\text { Difference }\end{array}$ \\
\hline \multirow[t]{3}{*}{$\begin{array}{l}\text { Coginitive self- } \\
\text { efficacy }\end{array}$} & $\begin{array}{l}\text { Between } \\
\text { Groups }\end{array}$ & 314.561 & 2.000 & 157.280 & 4.784 & 0.009 & $\begin{array}{l}\text { More than } 20 \\
>11-20 \text { years }\end{array}$ \\
\hline & $\begin{array}{l}\text { Within } \\
\text { Groups }\end{array}$ & 19068.235 & 580.000 & 32.876 & & & \\
\hline & Total & 19382.796 & 582.000 & & & & \\
\hline \multirow[t]{3}{*}{$\begin{array}{l}\text { Affective self- } \\
\text { efficacy }\end{array}$} & $\begin{array}{l}\text { Between } \\
\text { Groups }\end{array}$ & 430.446 & 2.000 & 215.223 & 4.356 & 0.013 & $\begin{array}{l}\text { More than } 20 \\
>11-20 \text { years }\end{array}$ \\
\hline & $\begin{array}{l}\text { Within } \\
\text { Groups }\end{array}$ & 28656.274 & 580.000 & 49.407 & & & \\
\hline & Total & 29086.720 & 582.000 & & & & \\
\hline \multirow[t]{3}{*}{$\begin{array}{l}\text { Psychomotor } \\
\text { self-efficacy }\end{array}$} & $\begin{array}{l}\text { Between } \\
\text { Groups }\end{array}$ & 35.933 & 2.000 & 17.967 & 0.771 & 0.463 & \\
\hline & $\begin{array}{l}\text { Within } \\
\text { Groups }\end{array}$ & 13518.966 & 580.000 & 23.309 & & & \\
\hline & Total & 13554.899 & 582.000 & & & & \\
\hline
\end{tabular}

The results for the fourth question of the study, whether the cognitive self-efficacy subscale scores of educators for effective communication is significantly different according to teaching branch, are presented in Tables 7 and 8.

Table 7: Descriptive analysis results of cognitive self-efficacy scale scores by teaching branch

\begin{tabular}{lllll}
\hline Subscales & Teaching Branch & N & M & SD \\
\hline Cognitive subscale & Classroom Teacher & 47 & 56.596 & 5.436 \\
& Turkish & 40 & 53.825 & 5.434 \\
& Elementary Mathematics & 42 & 52.000 & 5.640 \\
& Technology and Design & 44 & 53.182 & 6.557 \\
& Science & 40 & 52.325 & 4.565
\end{tabular}


Yahşi, Ö (2021). Examination of educators' self-efficacy for effective communication. Cypriot Journal of Educational Science. 16(2), 451-467 https://doi.org/10.18844/cjes.v16i2.5622

\begin{tabular}{llll} 
Turkish Language and Literature & 40 & 52.975 & 5.122 \\
Arts & 39 & 53.667 & 5.719 \\
Physical Education & 44 & 53.477 & 6.140 \\
Pre-school & 40 & 52.450 & 4.690 \\
Guidance and psychological counseling & 41 & 55.171 & 5.700 \\
Teacher of Mentally Handicapped & 44 & 52.864 & 6.508 \\
Religious Culture and Ethics & 38 & 53.605 & 5.921 \\
English & 44 & 53.114 & 5.253 \\
Social Sciences & 40 & 54.425 & 6.644 \\
\hline Total & 583 & 53.571 & 5.771 \\
\hline
\end{tabular}

Tables 7, 8 show that the teaching branch with the highest level of cognitive self-efficacy is Classroom Teaching ( $M=56.60)$. The lowest level is elementary mathematics education $(M=52)$. $A$ comparison of the branches shows effective communication self-efficacy levels are significantly higher than primary mathematics education and science teaching in favor of primary school teaching. While the cognitive self-efficacy of classroom teachers $(4.35 ; \mathrm{SD}=.42$ ) and guidance and psychological counselors $(4.24 ; \mathrm{SD}=.44)$ are excellent, the cognitive self-efficacy of teachers in other branches is at a good level.

Table 8: Cognitive self-efficacy analysis of variance by teaching branch

\begin{tabular}{llllllll}
\hline Subscale & $\begin{array}{l}\text { Source of } \\
\text { Variance }\end{array}$ & $\begin{array}{l}\text { Sum of } \\
\text { Squares }\end{array}$ & df & $\begin{array}{l}\text { Mean } \\
\text { Square }\end{array}$ & $F$ & $p$ & $\begin{array}{l}\text { Significant } \\
\text { Difference }\end{array}$ \\
\hline $\begin{array}{l}\text { Coginitive } \\
\text { self-efficacy }\end{array}$ & $\begin{array}{l}\text { Between } \\
\text { Groups }\end{array}$ & 835.590 & 13 & 64.276 & 1.972 & 0.021 & $\begin{array}{l}\text { Classroom.>elementary } \\
\text { Maths.; Classroom.>science. }\end{array}$ \\
& Within & & & & & & \\
& Groups & 18547.206 & 569 & 32.596 & & & \\
& Total & 19382.796 & 582 & & & & \\
\hline
\end{tabular}

The results for the fourth question of the study, whether the teachers' affective self-efficacy subscale scores for effective communication are significantly different according to teaching branch, are presented in Tables 9 and 10. 
Yahşi, Ö (2021). Examination of educators' self-efficacy for effective communication. Cypriot Journal of Educational Science. 16(2), 451-467 https://doi.org/10.18844/cjes.v16i2.5622

Table 9: Descriptive analysis results of affective self-efficacy scores according to teaching branch

\begin{tabular}{lllll}
\hline Subscale & Teaching Branches & $N$ & $M$ & SD \\
\hline Cognitive self-efficay & Classroom Teacher & 47 & 74.255 & 6.983 \\
& Turkish & 40 & 71.275 & 5.905 \\
& Elementary Maths & 42 & 70.238 & 7.315 \\
& Technology and Design & 44 & 70.727 & 7.910 \\
& Science & 40 & 69.375 & 7.217 \\
& Turkish Language and Literature & 40 & 71.275 & 6.465 \\
& Arts & 39 & 72.179 & 6.700 \\
& Physical Education & 44 & 72.250 & 7.456 \\
& Pre-school & 40 & 70.725 & 6.333 \\
Guidance and psychological counseling & 41 & 73.585 & 7.208 \\
Teacher of Mentally Handicapped & 44 & 71.432 & 7.768 \\
& Religious Culture and Ethics & 38 & 72.263 & 6.985 \\
English & 44 & 71.205 & 5.920 \\
Social Sciences & 40 & 73.200 & 7.683 \\
\hline Total & 583 & 71.731 & 7.069 \\
\hline
\end{tabular}

Tables 9 and 10 show that the branch with the highest level of affective self-efficacy is classroom teaching $(M=74.26)$. The lowest level is elementary mathematics teaching $(M=7.24)$. A comparison between branches shows there is no significant difference between affective self-efficacy scores. Scores between teaching branches, the self-efficacy of the teaching branches was found to have excellent and near-perfect values.

Table 10: Affective self-efficacy analysis of variance according to teaching branch

\begin{tabular}{lllllll}
\hline Subscale & Source of Variance & Sum of Squares & df & Mean Square & $\mathrm{F}$ & $\mathrm{p}$ \\
\hline Cognitive self-efficacy & Between Groups & 990.470 & 13 & 76.190 & 1.543 & 0.098 \\
& Within Groups & 28096.250 & 569 & 49.378 & & \\
& Total & 29086.720 & 582 & & & \\
\hline
\end{tabular}

The results for the fourth question of the study, whether there is a significant difference in the psychomotor self-efficacy subscale scores of the educators for effective communication according to teaching branch, are presented in Tables 11 and 12. 
Yahşi, Ö (2021). Examination of educators' self-efficacy for effective communication. Cypriot Journal of Educational Science. 16(2), 451-467 https://doi.org/10.18844/cjes.v16i2.5622

Table 11: Descriptive analysis results of psychomotor self-efficacy scores according to teaching branch

\begin{tabular}{lllll}
\hline Subscale & Teaching Branch & N & M SD \\
\hline Psychomotor self- & Cfficacy & 47 & 47.298 & 4.620 \\
& Classroom Teacher & 40 & 45.525 & 4.114 \\
& Turkish & 42 & 43.952 & 4.504 \\
& Elementary Maths & 44 & 44.364 & 5.855 \\
& Technology and Design & 40 & 44.100 & 4.125 \\
& Science & 40 & 45.425 & 4.373 \\
& Turkish Language and Literature & 39 & 45.231 & 5.436 \\
& Arts & 44 & 45.000 & 4.861 \\
& Physical Education & 40 & 44.575 & 3.986 \\
& Pre-school & 41 & 46.195 & 5.046 \\
& Guidance and Psychological Counselor & 44 & 44.841 & 5.203 \\
& Teacher of Mentally Handicapped & 38 & 45.079 & 5.154 \\
Religious Culture and Ethics & 44 & 45.568 & 4.060 \\
English & 40 & 46.025 & 5.337 \\
Social Sciences & 583 & 45.242 & 4.826 \\
\hline Total & & & \\
\hline
\end{tabular}

Tables 11 and 12 show that the branch with the highest level of psychomotor self-efficacy is classroom teachers $(M=47.30)$, as in other subscales. The lowest level is found in elementary mathematics teachers $(M=43.95)$. The psychomotor self-efficacy scale scores do not show a significant difference in scores between teaching branch. The arithmetic mean of the self-efficacy of teaching branches show that the classroom teachers $(4.30 ; S D=.42)$, the guidance and psychological counselors $(4.20 ; S D=.46)$ have an excellent level and teachers in other branches have a good level of self-efficacy.

Table 12: Results of analysis of variance on psychomotor self-efficacy according to teaching branch

\begin{tabular}{lllllll}
\hline Subscale & Source of Variance & Sum of Squares & df & Mean Square & $\mathrm{F}$ & $\mathrm{p}$ \\
\hline Psychomotor self-efficacy & Between Groups & 454.075 & 13 & 34.929 & 1.517 & 0.106 \\
& Within Groups & 13100.823 & 569 & 23.024 & & \\
& Total & 13554.899 & 582 & & & \\
\hline
\end{tabular}


Yahşi, Ö (2021). Examination of educators' self-efficacy for effective communication. Cypriot Journal of Educational Science. 16(2), 451-467 https://doi.org/10.18844/cjes.v16i2.5622

\section{Discussion and Conclusion}

Four main results were obtained from the findings of this study measuring the effective communication skills of educators. A significant difference was found in favor of managers in all three subscales of the inventory. This can be explained by the fact that administrators see communication as a more necessary requirement than do teachers to better maintain the education process. Affective self-efficacy was excellent in both groups. These findings are important in terms of affective selfefficacy as educators feel more competent in effective communication. The same finding can be interpreted to suggest that educators prioritize affective characteristics more in effective communication. The necessity for school administrators to be more sensitive to communication in order to carry out all the required aspects of education effectively may explain them achieving a higher level of this competence. Studies in the literature comparing administrators and teachers support the finding that positive communication between school leaders and teachers positively affects organizational climate (Doğan, Uğurlu, Yıldırım \& Karabulut, 2013; Rajhans, 2012 Halawah, 2005, Tabor, 2001). Other studies show that school principals' 21st century and communication skills have a positive effect on their leadership styles (Elekoğlu \& Demirdağ, 2020). In addition, some studies show a positive and significant relationship between managers' communication skills and organizational values of institutions (Fidan \& Küçükali, 2014; Ada \& Gümüş, 2012).

The second result suggests there is no significant difference between female and male educators. There was no significant difference by gender between all inventory subscale scores. Although this result may seem natural, many studies based on gender comparison have been conducted in the literature. These studies reveal no significant difference according to the gender variable (Tümkaya, 2011; Pehlivan, 2005; Memduhoğlu, 2015; Taşkın \& Hacıömeroğlu, 2010; Şimşek, 2003; Kozikoğlu \& Altunova, 2018). Other studies show that female teachers communicate more effectively than male teachers (Erdem \& Okul, 2015).

The subscale scores in terms of years of service show that educators with over 20 years have higher levels of cognitive self-efficacy, affective self-efficacy than teachers who have worked 11-20 years. There was no significant difference for 1-10 years of service or other periods. The higher self-efficacy perception of educators with over 20 years of service compared to those with 11-20 can be explained by the fact that this group has more work experience. However, results of the finding regarding teachers with 1-10 years of service experience do not support this opinion. Although there is no significant difference between teachers of 1-10 years and teachers of 11-20 years, the higher scores of teachers with 1-10 years of experience is partially related to attitudes toward the educational environment and communication of this less experienced group. It may also be related to the demographic characteristics of the sample. It is therefore necessary to examine different variables (attitude, burnout, anxiety, etc.) in similar sample groups, to take the same measurements and compare them to other groups in order to determine the reasons behind the results obtained. Studies have been carried out that show no significant difference in the variables of the institution where administrators are employed, professional seniority, and duration of service at the school (Bozcan \& Yalçınkaya, 2018; Oktay, 2008).

The fourth result of the research is the significance level of effective communication self-efficacy according to teaching branch. Accordng to the findings, the scores of classroom teachers and guidance and psychological counselors are higher on the basis of subscales. In the distribution of affective selfefficacy levels according to teaching branches in particular, which are shown as perfect and almost perfect. The differences between teaching branch, cognitive, affective self-efficacy levels show a significant difference in favor of classroom teachers compared to mathematics and science teachers. 
Yahşi, Ö (2021). Examination of educators' self-efficacy for effective communication. Cypriot Journal of Educational Science. 16(2), 451-467 https://doi.org/10.18844/cjes.v16i2.5622

This may be explained by the efforts classroom teachers go to to communicate with lower age groups. Classroom teachers' efforts to empathize more are particularly effective. Also, classroom teachers tend to experience more intense interaction with parents. Although showing no significant difference, the higher subscale scores of the guidance and psychological counselers compared to other teaching branches are due to the fact that these teachers are more open to communication, using therapeutic language. In particular, giving motivational interviews and gaining different perspectives due to their more intense interviews with administrators, students, parents are some of the reasons for this. Studies exist that show classroom teachers have high effective communication skills (Aküzüm \& Gültekin, 2017). Pre-service teachers' perceptions of communication skills or levels of communication skills are at a medium or above average level (Çetinkaya \& Alparslan 2011; Saracaloğlu, Yenice \& Karasakaloğlu, 2009; Gürşimşek, Ekinci, \& Selçioğlu, 2008; Baykara \& Pehlivan, 2005). In addition there are also studies showing that communication skills are related to professional motivation in the literature (Majid et.al, 2010). There are also studies showing that communication skills are related to professional motivation in the literature (Majid, Jelas, Azman \& Rahman, 2010).

\section{Recommendations}

In line with the results obtained from the research, the following suggestions are presented.

New studies can be conducted by increasing the sample numbers of the groups not included in this study. Given that affective self-efficacy scale scores of the Effective Communication Self-Efficacy Inventory are higher than other scales, studies could be conducted to examine affective characteristics in communication and to consider these characteristics together with other variables.

Another significant result is that there is a difference in terms of years of service. The reasons for the higher self-efficacy of those with 11-20 years of service should be investigated. New research could be conducted on the influence of years of service on effective communication self-efficacy and the reasons for this influence.

The three subscale results used in the study show that the participants are generally at an excellent and good level. However, these results are related to teachers' own self-efficacy beliefs. By using these scales together with various performance indicators in new studies, the relationship between teachers' performance and self-efficacy could be analyzed.

\section{References}

Ada,Ş \& Gümüş, S (2012). The reflection of instructional leadership concept on educational administration master's programs: a comprasion of Turkey and the United State of America. International Online Journal $\begin{array}{llll}\text { of } \quad \text { Educational 4ciences 462-474. } & \text { 4(2), }\end{array}$ https://iojes.net/index.jsp?mod=tammetin\&makaleadi=\&makaleurl=IOJES_674.pdf\&key=41214

Aküzüm, C. \& Gültekin, S. Ö. (2017). The investigation of relationship between primary school teachers' communication skills an classroom management skills.. Electronic Journal Of Education Sciences, 6(12), 88-107. https://doi.org/10.26449/sssj.1427

Atik, L. (2009). The effect of communication skills of primary school administrators on total quality management. (Unpublished master's thesis). Selçuk University, Konya http://acikerisimarsiv.selcuk.edu.tr:8080/xmlui/handle/123456789/10112 
Yahşi, Ö (2021). Examination of educators' self-efficacy for effective communication. Cypriot Journal of Educational Science. 16(2), 451-467 https://doi.org/10.18844/cjes.v16i2.5622

Bagin, D., Gallagher, D. R., \& Moore, E. H. (2008). The communication process. In A. E. Burvikovs (Ed.), The school and community relations. (9th ed., pp. 74-89).MA: Pearson.

Bagin, D., Gallagher, D. R., \& Moore, E. H. (2008). Communicating with internal publics. In A. E. Burvikovs (Ed.), The school and community relations. (9th ed, pp. 90-118). MA: Pearson.

Bandura, A. (1986). Social foundations of thought and action: A social cognitive theory. Prentice-Hall, Inc. https://doi.org/10.5465/amr.1987.4306538

Bandura, A. (1997). Self-efficacy: Toward a unifying theory of behavioral change. Psychological Review, 84(2), 191-215. https://doi.org/10.1037/0033-295x.84.2.191

Baykara Pehlivan, K. (2005). A study on perception of communication skills of preservice teachers. Ilköğretim Online, 4 (2), 17-23. http://ilkogretim-online.org.tr/index.php/io/article/viewFile/2014/1850

Bozcan E. Ü. \& Yalçınkaya, M (2018). The relationship between ethical leadership behavirs and communcation skills of school administrators and organizational commitment levels of teachers in primary education institutions. Turkish Studies Educational Sciences, 13(27), 263-284. https://doi.org/10.7827/turkishstudies.14344

Buluş, M., Atan, A., \& Erten Sarıkaya, H. (2017). Effective communication skills: A new conceptual framework and scale development study, International Online Journal of Educational Sciences, 9(2), 575-590. http://acikerisim.pau.edu.tr/xmlui/handle/11499/26633

Bylund, C. L., Brown, R. F., Ciccone, B. L., Levin, T.T., Geuguen, J. A., Hill, C., \& Kissane, D. W. (2008). Training faculty to facilitate communication skills training: Development and evaluation of a workshop. Patient Education and Counseling 70 430-436. https://doi.org/10.1016/j.pec.2007.11.024

Ceylan, G. (2008). The effect of teache-student interaction on the classroom atmosphere (Unpublished doctoral thesis), Selçuk University Institute of Social Sciences.http://acikerisimarsiv.selcuk.edu.tr:8080/xmlui/bitstream/handle/123456789/9642/219207.pdf? sequence $=1$ \&isAllowed $=\mathrm{y}$.

Cotton, J. A. (2003). The instructional leadership proficiencies of elementary principals: A study of preparation and continuing professional development needs (Doctoral dissertation, The George Washington University, 2003). Dissertation Abstracts International, 3083797.

Çetinkanat, C. (1998). Teacher communication skills from the perspective of prospective teachers and inspectors. Kuram ve Uygulamada Egitim Yönetimi Dergisi, 4(2), 209-221. https://doi.org/10.14527/9786053644309.08

Çetinkaya, Ö. \& Alparslan, A. G. A. M. (2011). The effect of emotional intelligence on communication skills An investigation on university students. Süleyman Demirel Üniversitesi iktisadi ve İari Bilimler Fakültesi Dergisi, 16(1), 363-377. https://doi.org/10.18657/yecbu.33859

Çınar, O. (2010). Principal effectiveness in communication process. Dumlupınar Üniversitesi Sosyal BilimlerDergisi,26(1),267-

276.http://birimler.dpu.edu.tr/app/views/panel/ckfinder/userfiles/17/files/DERG_/26-1/267-276.pdf

Doğan, S., Uğurlu, C.T., Yıldırım, T., \& Karabulut, E. (2013). Evaluation of the communication process between school administrators and teachers according to teachers' opinions.. Turkish Journal of Education, January, 3(1), 34-47. https://doi.org/10.19128/turje.181074

Doyle, D., Copeland H. L, Bush, D., Stein, L., \& Thompson, S. (2011). A course for nurses to handle difficult communication situations. A randomized controlled trial of impact on self-efficacy and performance. Patient Education and Counseling 82 100-109. https://doi.org/10.1016/j.pec.2010.02.013 
Yahşi, Ö (2021). Examination of educators' self-efficacy for effective communication. Cypriot Journal of Educational Science. 16(2), 451-467 https://doi.org/10.18844/cjes.v16i2.5622

Elekoğlu, F. \& Demirdağ, S. (2020). Investigation of school principals' 21st century skills and leadership styles according to teachers' perceptions. Karaelmas Journal of Educational Sciences 8 (2020) 101-117. http://ebd.beun.edu.tr/index.php/KEBD/article/view/236

Erdem, A. \& Okul, Ö.( 2015). Primary school teachers' communication skills with students. Çağdaş Yönetim Bilimleri Dergisi, 2(1), 1-8. https://dergipark.org.tr/en/download/article-file/408082

Fidan, M. \& Küçükali, R. (2014). Administrators' communication skills and organizational values in primary education institutions. Eğitim Bilimleri Araştırmaları Dergisi 4(1) 317-334. https://doi.org/10.12973/jesr.2014.41.16

Field, A. (2013). Discovering statistics using. SAGE.

Guerrero, L\& Floyd K. (2005). Nonverbal communication in close relationships. Lawrence Erlbaum

Gürşimşek, I., Ekinci Vural, D., \& Selçioğlu, D. E. (2008). The relationship between emotional intelligence and communication skills of teacher candidates. Mehmet Akif Ersoy Üniversitesi Eğitim Fakültesi Dergisi. 16, 111. https://doi.org/10.21764/maeuefd.569593

Halawah, I. (2005). The relationship between effective communication of high school principal and school climate. Education, 126(2). https://eric.ed.gov/?id=EJ765683

Heslep, R. D. (1998). Communication as the absolute foundation of philosophy. Educational Theory, 48(1). https://www.researchgate.net/publication/228029787_Communication_as_the_absolute_foundation_of _philosophy

Karasar, N. (2006). Bilimsel araştırma yöntemi. Nobel Yayın Dağıtım.

Kozikoğlu, i.., \& Altunova, N. (2018). The predicative power of prospective teachers' self-efficacy perceptions of 21st century skills fot heir lifelong learning tendencies. Journal of Higher Education \& Science/Yüksekögretim ve Bilim Dergisi, 12(3). https://doi.org/10.47477/ubed.781499

Khodadadi, E., Ebrahimi, H., Mooghaddasian, S., \& Babapour, J. (2013). The Effect of Communication Skills Training on Quality of Care, Self-Efficacy, Job Satisfaction and Communication Skills Rate of Nurses in Hospitals of Tabriz, Iran. Journal of Caring Sciences, 2(1), 27-27. https://doi.org/10.5681/jcs.2013.004

Kowalski, T. J. (2006). The school superintendent: Theory, practice, and cases (2nd ed.).Sage

Majid, N. A., Jelas, Z. M., Azman, N., \& Rahman, S. (2010). Communication Skills and work motivation amongst expert teachers. Procedia Social and Behavioral Sciences. 7(C), 565-567. https://doi.org/10.1016/j.sbspro.2010.10.075

Martin, H.Z, Jandaghi, G, Karimi, F.H. \& Hamidizadeh (2010). Relationship between interpersonal communication skills and organizational commitmet (Case study: Jahad Keshavarzi and University of Qom, Iran). European Journal of Social Sciences 13(3) 387-398. https://www.semanticscholar.org/paper/Relationship-between-Interpersonal-Communication-of-MatinJandaghi/2eec720d7ca2b7437398398fc84244a0ab61bc1f\#references

Meek, A. (1999). Communicating with the public: A guide for school leaders. Association for Supervision and Curriculum Development.

Memduhoğlu, H. B. (2015). Examining primary school administrators' according to the perceptions of teachers and administrators. Education and Science, 40(177). http://dx.doi.org/10.15390/EB.2015.1677

Okoro, E. Washington, M \& Thomas =. (2017). The impact of interpersonal communication skills on organizational effectiveness and social sefl-efficacy: A synthesis. International Journal of Language and Lingusitics, 4(3) 28-32. http://www.ijllnet.com/journals/Vol_4_No_3_September_2017/3.pdf

Pallant, J. (2001). SPSS survival manual. Open University Press. 
Yahşi, Ö (2021). Examination of educators' self-efficacy for effective communication. Cypriot Journal of Educational Science. 16(2), 451-467 https://doi.org/10.18844/cjes.v16i2.5622

Pehlivan, B. K. (2005). A study on perception of communication skills of preservice teachers. Elementary Education Online, 4(2), 17-23. http://ilkogretim-online.org.tr/index.php/io/article/viewFile/2014/1850

Rajhans, K. (2012). Effective organizational communication: a key to employee motivation and performance, Interscience Management Review, 2(2), 81-85. https://doi.org/10.47893/imr.2009.1040

Raufelder, D., Drury, K., Jagenow, D., Hoferichter, F., \& Bukowski, W. (2013). Development and validation of the relationship and motivation(REMO) scale to assess students' perceptions of peers and teachers as motivators in adolescence. Learning and Individual Differences, 24, 182-189. https://doi.org/10.1016/j.lindif.2013.01.001

Saracaloğlu, S., Yenice, N., \& Karasakaloğlu, N. (2009). The relationship between communication and problem solving skills and reading interest and habits of candidate teachers'. Yüzüncü Yıl Üniversitesi Eğitim Fakültesi Dergisi. 6(2), 187-206. https://doi.org/10.31463/aicusbed.496472

Shama, M. E., Meky, F. A., Enein, N. Y., \& Mahdy, M. (2009). The effect of a training program in communication skills on primary health care physicians knowledge, attitudes and self-efficacy. J.Egypt Public Health Assoc. $84(3 \& 4)$ http://citeseerx.ist.psu.edu/viewdoc/download?doi=10.1.1.683.7835\&rep=rep1\&type=pdf

261-283.

Sharifirad, G. R., Rezaeian, M., Jazini, A., \& Etemadi, Z. S. (2020). Knowledge, attitude and performance of academic members regarding effective communication skills in education. J Edu Health Promot 2012;1:42. https://doi.org/10.4103/2277-9531.104812

Smith, W., Guarino, A. J., Strom, P., \& Reed, C. (2003). Principal self-efficacy and effective teaching and learning environments. School Leadership and Management, 23(4), 505-508. https://doi.org/10.1080/1363243032000151015

Stewart, C., Martin, K., \& Tyrone, P. (2005). Managing and organization. Sage..

Şimşek, Y. (2003). The relationship between the school principals' communication skills and the school culture, Unpublished doctoral thesis, Anadolu University Institute of Educational Sciences, Eskişehir. https://doi.org/10.16986/huje.2020058754

Şimşek, Y. \& Altınkurt, Y. (2009). Opinions of vocational high school teachers related to commuication skills of their school principals.. Akademik Bakış, 17, 1-16. https://doi.org/10.24106/kefdergi.3055

Tabor, B. (2001). Conflict management and interpersonal communication style of the elemantary principal, Unpublished doctoral thesis, Colombia, Missouri University.

Taşkın, Ç. \& Hacıömeroğlu, Ç. (2010) .Adaptation of the teachers' self-efficacy beliefs systems-self form and primary teachers' self-efficacy beliefs. Dokuz Eylül Üniversitesi Buca Eğitim Fakültesi Dergisi 27, 63-75 https://doi.org/10.24106/kefdergi.2712

Tschannen-Moran, M. \& Gareis, C. R. (2004). Principals' sense of efficacy: assessing a promising construct. Journal of Educational Administration, 42(4), 573-585. https://doi.org/10.1108/09578230410554070

Tümkaya, S. (2011). Investigation of communication skills and attitude to teaching of the students of primary school teaching. Çukurova University Journal of Social Sciences Institute, 20(2), 49-62. http://eds.a.ebscohost.com/eds/pdfviewer/pdfviewer?vid=0\&sid=2058f206-e90b-4075-8846$9 \mathrm{~b} 8 \mathrm{c} 25 \mathrm{c} 7 \mathrm{a} 875 \% 40$ sdc-v-sessmgr03

Yahşi, Ö. \& Aydın, S. (2020). Development of effective communication self-efficacy inventory: avalidity-reliability study. International Journal of Current Approaches in Language, Education and Social Sciences, 2(1), 257275. https://doi.org/10.35452/caless.2020.13 